\title{
The Middleman Effect: The Ethical \\ Consequences of Paying Others to Act on One's Behalf
}

\author{
Chris Macdonald ${ }^{1^{*}}$ \\ ${ }^{1}$ Skylab, United Kingdom \\ *Corresponding author: Chris Macdonald: chrismacdonald@dr.com
}

\section{OPEN ACCESS}

Citation: Macdonald C. (2020) The Middlemen Effect: The Ethical Consequences of Paying Others to Act on One's Behalf. Open Science Journal 5(1)

Received: $15^{\text {th }}$ February 2020

Accepted: $9^{\text {th }}$ March 2020

Published: $16^{\text {th }}$ April 2020

Copyright: (C) 2020 This is an open access article under the terms of the Creative Commons Attribution License, which permits unrestricted use, distribution, and reproduction in any medium, provided the original author and source are credited.

Funding: The author received no specific funding for this work

Competing Interests: The author has declared that no competing interests exist.

\begin{abstract}
:
In a time where we are increasingly made aware of unsustainable and unethical corporations, it is important to ask, why do consumers continue to purchase their products? Why aren't more people 'voting' with their dollar and demanding higher environmental and ethical standards? Is it simply a lack of awareness or are there also underlying factors that increase our tolerance to unethical conduct? This paper reveals a phenomenon that shares similarities to the bystander effect: the middleman effect. The results of Experiment 1 reveal that participants are more likely to purchase unethical products if there are more middlemen involved in the manufacturing process. Experiment 2 reveals that while maintaining the same number of middlemen in a given situation, it is significant when the unethical conduct takes place in a series of linear events; as the unethical conduct gets closer to the point of purchase, the tolerance of unethical behaviour decreases. The middleman effect may be an important part of the puzzle which facilitates those around the world striving for an ethical and sustainable future.
\end{abstract}

Keywords: Ethics, Morality, Middlemen, Business practices, Bystander effect, Ethical decision-making, Psychology, Sociology, Economics, Morality, Disconnecting agents, Cognition, Decision-making, Sustainability, Middleman effect 


\section{Introduction}

When we study humankind we often discover many fantastic abilities. Ones that we might even feel rather proud of: the ability to survive for months without food (Stewart et al, 1973; Finnell et al, 2018), the ability to run for hundreds of miles (Millet et al, 2012; Knechtle et al, 2018), the ability to create positive scientific solutions (Powell et al, 2008; Chia et al, 2018), the want to help others (Warneken et al, 2006; Barragan et al, 2014). However, with the light comes some darkness as we have also discovered many unsettling flaws: the potential to harm ourselves (Brådvik, 2018; Roh et al, 2018), others (Lin et al, 2018; Stone, 2019), and the environment (Cook et al, 2013; Cook et al, 2016), the potential to standby in great numbers and watch as unethical actions play out (Plotner et al, 2015; Hortensius et al, 2018).

The bystander effect is indeed very unsettling, but it would be incredibly unwise - and somewhat ironic - to turn a blind eye to such shortcomings. Tackling it head-on and deciphering the underlying mechanisms can help us evolve beyond the more undesirable traits of us Homo sapiens.

The most well-known example of the bystander effect is that of Kitty Genovese. In 1964, Kitty was brutally attacked on her way home from work. When she screamed out in agony, thirty-eight of her neighbors rushed to their windows and watched in complete terror. Even though it took over half an hour to murder Kitty, none of these onlookers tried to intervene or even call the police (Latané et al, 1969).

While it can be tempting to narrativize the inaction of others as apathetic or mean-spirited, there is often something more complicated going on. People, in general, do want to help and do want to support helpful others (Warneken et al, 2006; Hamlin et al, 2007; Hamlin et al, 2011; Barragan et al, 2014), but being a part of an unknown group has unfortunate side-effects.

Further studies have revealed that individuals are far more likely to intervene when there are fewer people involved in the situation (Latané et al, 1969; Brody et al, 2016). One explanation of this could be due to social anxieties and the fear of failure and judgment in front of a crowd. However, further experiments have shown that when the other bystanders are clearly unable to intervene - such as behind a barrier - then the participant is significantly more likely to help, suggesting that the effect may also be due to a diffusion of responsibility rather than mere social anxiety (Plötner et al, 2015). As part of an unfamiliar crowd, it is not immediately clear who should help.

In addition to this, the events where people don't step up often require untrained and unrehearsed action, therefore, no one in the crowd may have a clear idea of how best to proceed (Latané et al, 1969). In hindsight, one can simplify the scenario by interpreting the possible decisions as binary: help or do nothing. However, to help would involve a series of decisions (Latané et al, 1969), ones that are often unique and unplanned.

If one were to enter a given situation with a familiar intention, it is understandable that an unforeseen paradigm may cause freezing as one would have to reevaluate and think on the spot without the help of advice, prior experience, or known cultural stereotypes (Latané et al, 1969).

This freezing carries with it a restrictive consequence. As a communicative and social species, we automatically scan for social cues (Visser et al, 2018), and when those around us are frozen, this can be problematic. Latané and Darley state that a frozen group can lead to pluralistic ignorance, where the individual is 
influenced by what could appear to be a lack of concern from others, rendering the situation less serious yet more confusing (Latané et al, 1969).

The lack of connection to the other bystanders appears to be a highly significant factor. When comparing groups of the same number, it has been shown that when they know each other they are far more likely to get involved in the situation (Latané et al, 1969; Brody et al, 2016). In further support of connection being a significant factor, it has been shown that greater proximity (Brody et al, 2016) and direct eye-contact with potential victims (Valentine,1980) significantly decreases the bystander effect.

Given that the bystander effect's underlying mechanisms appear to involve forms of disconnection, perhaps it is no surprise that it is currently found within the modern domain of cyberbullying (Brody et al, 2016; Cieciura, 2016).

This led me to consider the many scenarios in modern-day life where we can become part of a large group without direct authentic connections. Could these moments also be vulnerable to unethical decisions and inaction?

I began to investigate the chains of production with highly processed products. Relatively speaking, this is also rather new territory for Homo sapiens. In hunter-gatherer times we would have direct connections to the source of our diets and technology. Yet in modern times, a single fast-food item can contain hundreds of ingredients that may involve hundreds of people from all around the world (Freequill, 2018). This dramatically increases disconnection, especially when we consider the inclusion of multiple middlemen.

If we take an apple as a simplified example, most people are not personally plucking the apple from the tree, they are instead purchasing their apple from the supermarket. And as the cashier didn't pick the apple either, the supermarket could be viewed as a middleman. What's more, the supermarket is likely to have purchased the apple from an apple seller rather than directly from the farmer, therefore we can see a chain of multiple middlemen. This chain quickly grows when we consider additional elements such as packaging, storage, and transportation. And it grows exponentially further when we consider highly processed goods with numerous ingredients or components.

Therefore we have scenarios where consumers are increasingly disconnected from the source. And as a result, they are significantly less likely to be aware of how the product is created, and how it made its way to the supermarket shelf.

One could argue that this lack of connection facilitates unethical practices. That is to say that as there are more middlemen involved, there are several direct connection breakers that could facilitate clandestine activities thus increasing the opportunity for unethical behavior. However, in addition to this, could this chain of individuals also lead to a diffusion of responsibility and thus increase tolerance of unethical behavior? In other words, is there a bystanderesque effect in extended chains of production? Is there a middleman effect?

This paper reveals two new experiments that explore the potential of a middleman effect. Experiment 1 explores the hypothesis that participants will be more likely to tolerate unethical behavior if there are more middlemen involved in a given situation. Experiment 2 explores the hypothesis that participants will be more likely to support unethical behavior if there are more middlemen after the unethical conduct has taken place. That is to say that while maintaining the same number of middlemen in a given situation, it is hypothesized that it is significant when the unethical conduct takes place in a series of events. Based on the bystander effect, it is predicted that if there are more middlemen between an unethical incident and a consumer, then the consumer will be more likely to purchase the product despite it being revealed to be ethically compromised. 


\section{Experiment 1}

Experiment 1 explores the hypothesis that participants will be more likely to support unethical behavior if there are more middlemen involved in a given situation.

\section{Participants}

100 US Students took part in the experiment. In an attempt to reduce variables all participants also had the following in common: aged 18-25, Caucasian ethnicity, and English-only spoken at home.

\section{Procedure}

The students were randomly assigned to one of two groups: Group AD and Group AN (50 participants per group).

Each participant was asked to complete an anonymous survey. Before starting they were reminded that there is no right or wrong answer and that they should give their honest opinion.

As part of the survey, the participants had to read through a hypothetical scenario before answering a relevant question. The scenario explores the production of a product, whereby each ingredient is supplied to the manufacturer by a unique middleman, thus the more ingredients in the product, the more middlemen involved.

The scenario states that the participant normally purchases the product once a week but they learn that one of the middlemen cuts corners to increase profit. To reduce overheads this middleman uses a supplier that dumps toxic waste into a river rather than paying for it to be responsibly recycled. The participants were then asked if they would continue to purchase the product after being informed of the unethical conduct.

The scenario given to Group $\mathrm{AD}$ contained four middlemen (Mr. A, Mr. B, Mr. C, and Mr. D). Whereas the scenario given to Group AN contained fourteen middlemen (Mr. A, Mr. B, Mr. C, and so on). Aside from the number of middlemen involved, both scenarios where identical. In both hypothetical scenarios, Mr. C is the only middleman revealed to conduct unethical behavior.

*A note on the survey delivery method.

A known concern with experiments in social sciences is that the researchers conducting the experiment might be able to influence the results (Rosenthal, 1966; Conty et al, 2010; Doyen et al, 2012), even without intending to do so. To protect against this, a third-party UK organization was used to distribute all of the surveys used in the experiments. The third-party uses an automated distribution service and they were unaware of the purpose of the survey or any hypotheses attached to it. None of the participants were permitted to enter more than one experiment and/or more than one group. That is to say that as there are two experiments in this paper, with 100 participants each, there are 200 unique participants in total; all of them were paid for their participation. 


\section{Results}

In Group AD, $26 \%$ stated they would still purchase the product $(\mathrm{N}=50)$.

In Group AN, 38\% stated they would still purchase the product $(\mathrm{N}=50)$.

In accordance with the hypothesis, there was a significant difference between the two groups, $\mathrm{t}(97)=-1.28, \mathrm{p}=.2$. In particular, the data revealed that the group with fewer middlemen were less likely to support unethical behavior.

When there were four middlemen involved, $26 \%$ of the participants stated that they would continue to purchase the product despite learning about the unethical conduct. Whereas, when there were fourteen middlemen involved, $38 \%$ of the participants stated that they would continue to purchase the product. Therefore, more middlemen resulted in a $12 \%$ increase in consumer tolerance of unethical corporate practices.

\section{Experiment 2}

Experiment 2 explores the hypothesis that participants will be more likely to support unethical behavior if there are more middlemen after the unethical conduct. That is to say that while maintaining the same number of middlemen in a given situation, it is hypothesized that it is significant when the unethical conduct takes place in a series of linear events.

\section{Participants}

100 US Students took part in the experiment. In an attempt to reduce variables, all participants also had the following in common: aged 18-25, Caucasian ethnicity, and English-only spoken at home.

\section{Procedure}

The students were randomly assigned to one of two groups: Group B and Group E (50 participants per group).

Each participant was asked to complete an anonymous survey. Before starting they were reminded that there is no right or wrong answer and that they should give their honest opinion.

As part of the survey, the participants had to read through a hypothetical scenario before answering a relevant question. The scenario explores a linear chain of events that lead to the production of a pencil. Each step is facilitated by a unique middleman: Mr. E, Mr. D, Mr. C, Mr. B, and Mr. A.

Mr. $\mathrm{E}$ is the middleman at the beginning of the chain of events, as he buys wood and sells it to the woodcarver. The woodcarver then makes wooden tubes for pencil production. Mr. D buys the wooden tubes and sells them to the painter. The painter then paints the wooden tubes. Mr. C buys the painted wooden tubes and sells them to the graphite worker. The graphite worker then inserts graphite into the painted wooden tubes to finish the pencils. Mr. B buys 
the completed pencils and sells them to Mr. A. Mr. A sells the pencils to the public from his stationery store.

The participants are asked to imagine that they wanted to purchase one of the pencils but they learn that one of the middlemen is using unethical business practices.

The unethical scenario and the number of middlemen involved in the situation remained consistent between the two groups, the only difference is which middleman is revealed to be unethical. In Group E's hypothetical scenario, Mr. E is revealed to partake in unethical conduct, whereas in Group B's hypothetical scenario, Mr. B is revealed to partake in unethical conduct. Therefore from Group E's perspective, there are four middlemen between their purchase and the unethical conduct. Whereas from Group B's perspective, there is only one middleman between their purchase and the unethical conduct.

Below is the chain of middlemen for both groups with the unethical middleman in bold font:

Group E: Source $>$ Mr. E $>$ Mr. D $>$ Mr. C $>$ Mr. B $>$ Mr. A $>$ Consumer

Group B: Source $>$ Mr. E $>$ Mr. D $>$ Mr. C $>$ Mr. B $>$ Mr. A $>$ Consumer

\section{Results}

In Group B, $66 \%$ stated that they would still purchase the product $(\mathrm{N}=50)$.

In Group E, $74 \%$ stated that they would still purchase the product $(\mathrm{N}=50)$.

In accordance with the hypothesis, there was a significant difference between the two groups, $\mathrm{t}(97)=-0.86, \mathrm{p}=.3$. In particular, the data revealed that the group with more middlemen between them and the unethical conduct was more likely to purchase the product.

When there were four middlemen following the unethical behavior, $74 \%$ of the participants stated that they would still purchase the product. Yet when there was only one middleman following the unethical behavior, $66 \%$ of the participants stated that they would still purchase the product.

\section{Discussion}

While there is mounting work aiming to decipher how corporations could become more ethical (Hegarty et al, 1978; Tenbrunsel et al, 2003; Trevino et al, 2006), less research is pursuing why consumers continue to support unethical corporations. And when looking specifically at the research of middlemen, the focus appears to be exploring how middlemen can help or hinder corporations rather than how they may facilitate or perpetuate unethical conduct (Rubinstein et al, 1987; Lizzeri, 1999; Rust et al, 2003; Wright et al, 2014; Krakovsky, 2015; Biglaiser et al, 2017; Biglaiser et al, 2018).

When looking at unethical corporate behaviour, I believe it is well worthwhile considering both sides of the story: corporate unethical conduct, and consumer ignorance or tolerance. In many situations, effective reform can be enforced from the end of the production line, as once the majority of consumers refuse to purchase a given product, corporate change is inevitable.

It has been suggested that when participants feel that they have less control of a situation they are more tolerant of unethical conduct (Gottfredson et al, 
1990; Baumeister et al, 2001; Trevino et al, 2006; Mead et al, 2009). Perhaps being the last link in an extended chain of events can make consumers feel as though they have little power. Perhaps it is better to view the chain of events as a bicycle chain, where the last link is connected to the first, thus creating a closed-loop. While the consumer may not have been involved directly in the unethical practice, when they purchase the item, they are enabling it to continue.

This may be at the heart of the middleman effect. In addition to a bystanderesque component, where there is a diffusion of responsibility, there may also be the illusion of complete powerlessness, as they may view themselves as the last stop of a journey. Perhaps, as a result, consumers may feel less guilt as influencing the unethical conduct may appear less likely. Lower levels of guilt have been strongly related to increased unethical behaviour in prior research and so perhaps it is also part of the middleman effect (Tangney et al, 2007; Cohen et al, 2011; Cohen et al, 2012; Arli et al, 2017).

What leads to unethical decision-making is notoriously complex, containing many nuanced factors such as culture, age, wealth, personality, and philosophical beliefs (Tenbrunsel et al, 2008; Kish-Gephart et al, 2010; Macdonald, 2019), yet it is important to remember to factor in the systems that we are part of and the complete chain of events that play a role in a seaming isolated moment.

Multiple middlemen might be influencing unethical behavior in many ways. As there are more apparent breaks in the production chain there could be more opportunities for corporations to cut corners or partake in covert activities. When there are more intermediaries involved perhaps the consumer is less aware of the complete story. And the middleman effect shows us that if there is unethical behavior, and the consumer is aware, they may be more likely to tolerate it when there are more middlemen involved. This compounding effect is disconcerting when we consider that current transactions are almost exclusively made through multiple middlemen (Biglaiser et al, 2017).

\section{Concluding Remarks}

It is interesting to consider current unethical tolerance under a new paradigm. Suppose that there were no middlemen involved and that an item's components were sourced, assembled, and sold from one location, with complete transparency. In this hypothetical scenario, one could obtain their desired item directly from the source, similar to the hunter-gatherer of old. They would be communicating with the person responsible for every step. In this paradigm, when purchasing the item, it is more apparent that the consumer is funding each step and the continuation or even growth of the operation.

It is interesting to consider whether we would still purchase some of our modern items if every link in the production chain were grouped together and laid out in front of us in this fashion. Would we still purchase certain unsustainable products if we saw the acres of rainforest that had to be cleared every second? (Holley, 2017) Would we still buy palm oil if we saw the trees on fire, inhabited by one of the last families of orangutans? (Scientific American, 2012) Would we still buy designer clothing if we could see the textile factories poisoning the rivers in Bangladesh and subsequently poisoning the local communities and wildlife? (Webber, 2017) Would we still buy smartphones if we saw the four-year-old children working in the harmful and unregulated cobalt 
mines of the Congo? (Frankel, 2016) And would we purchase certain brands of chocolate if we saw the child slave workers of the Ivory Coast? (Clarke, 2015)

If it were directly in front of us and more evident that our consumption can support unethical conduct, would we be more inclined to 'vote' with our dollar?

The unpleasant truth is that the clothes we are wearing, the food we are about to eat, and the items that fill our homes, are likely to carry some form of suffering. And this suffering might be destined to grow when we feel as though we are disconnected from the process.

In our current systems, the recurring crimes are so jarring as they conflict with fundamental human values. It is a sad state of affairs when you can make a video of a current factory with no edits, narration, or emotional music, and when you show that video to the consumer they may cry, feel angry and incredibly misled. When the truth can hurt so deeply, we have to create a better truth.

\section{References:}

Arli D, Leo C. 2017. Why do good people do bad things? The effect of ethical ideology, guilt proneness, and self-control on consumer ethics. Asia Pacific Journal of Marketing and Logistics 29:(5) 1055-1078 doi.org/10.1108/APJML-11-2016-0218

Barragan RC, Dweck CS. 2014. Reciprocity triggers children's benevolence. Proceedings of the National Academy of Sciences 111:(48) 17071-17074 doi.org/10.1073/pnas.1419408111

Baumeister RF, Exline JJ. 1999. Virtue, personality, and social relations: Self- control as the moral muscle. Journal of Personality 67 1165-1194 doi.org/10.1111/1467-6494.00086

Biglaiser G, Li F. 2018. Middlemen: the good, the bad, and the ugly. The RAND Journal of Economics 49:(1) 3-22 doi.org/10.1111/1756-2171.12216

Biglaiser G, Li F, Murray C, Zhou Y. 2017. The Role of Intermediaries: Theory and Evidence from Used Car Dealers. SSRN 1-56 dx.doi.org/10.2139/ssrn.3003562

Brådvik L. 2018. Suicide Risk and Mental Disorders. Int J Environ Res Public Health 15(9):2028 doi.org/10.3390/ijerph15092028

Brody N. Vangelisti AL. 2016. Bystander intervention in cyberbullying. Communication Monographs 83:(1) 94-119 doi.org/10.1080/03637751.2015.1044256

Chia S, Habchi J, Michaels TCT, Cohen SIA, Linse S, Dobson CM, Knowles TPJ, Vendruscolo M. 2018. SAR by kinetics for drug discovery in protein misfolding diseases. Proceedings of the National Academy of Sciences 115:(41) 10245-10250 doi.org/10.1073/pnas.1807884115

Cieciura J. 2016. A Summary of the Bystander Effect: Historical Development and Relevance in the Digital Age. Inquiries Journal 8:(11)inquiriesjournal.com/a?id=1493

Clarke JS. 2015. Child labour on Nestlé farms: chocolate giant's problems continue. The Guardian Sep 2 theguardian.com/global-development-professionals-network/2015/sep/02/child-labour-onnestle-farms-chocolate-giants-problems-continue

Cohen TR, Panter AT, Turan N. 2012. Guilt Proneness and Moral Character, Current Directions in Psychological Science 21:(5) 355-359 doi.org/10.1177/0963721412454874

Cohen TR, Wolf ST, Panter AT, Insko CA. 2011. Introducing the GASP scale: A new measure of guilt and shame proneness. Journal of Personality and Social Psychology 100 947-966 doi.org/10.1037/a0022641

Conty L, Gimmig D, Belletier C, George N, Huguet P. 2010. The cost of being watched: Stroop interference increases under concomitant eye contact. Cognition 115: 133-139 doi.org/10.1016/j.cognition.2009.12.005

Cook J, Nuccitelli D, Green SA, Richardson M, Winkler B, Painting R, Way R, Jacobs P, Skuce A. 2013. Quantifying the consensus on anthropogenic global warming in the scientific literature. Environmental Research Letters 8:(2) opscience.iop.org/article/10.1088/17489326/8/2/024024/meta

Cook J, Oreskes N, Doran PT, Anderegg WRL, Verheggen B, Maibach EW, Carlton JS, Lewandowsky S, Skuce AG, Green SA, Nuccitelli D, Jacobs P, Richardson M, Winkler B, Painting R, Rice K. 2016. Consensus on consensus: a synthesis of consensus estimates on humancaused global warming. Environmental Research Letters 11:(4) doi.org/10.1088/17489326/11/4/048002

Doyen S, Klein O, Pichon CL, Cleeremans A. 2012. Behavioral Priming: It's All in the Mind, but Whose Mind? PLoS ONE 7(1) e29081 doi.org/10.1371/journal.pone.0029081 
Finnell JS, Saul BC, Goldhamer AC, Myers TR. 2018. Is fasting safe? A chart review of adverse events during medically supervised, water-only fasting. BMC complementary and alternative medicine 18:(1) 67 doi.org/10.1186/s12906-018-2136-6

Frankel TC. 2016. The cobalt pipeline. The Washington Post Sep 30 washingtonpost.com/graphics/business/batteries/congo-cobalt-mining-for-lithium-ion-battery

Freequill. 2018. What's going on? How can we help? Vancouver, BC: Illuminate Press

Gottfredson MR, Hirschi T. 1990. A general theory of crime. Stanford, CA: Stanford University Press

Hamlin JK, Wynn K, Bloom P. 2007. Social evaluation by preverbal infants. Nature 450:(7169) 557559 doi.org/10.1038/nature06288

Hamlin JK, Wynn K. 2011. Young infants prefer prosocial to antisocial others. Cognitive development 26:(1) 30-39 doi.org/10.1016/j.cogdev.2010.09.001

Hegarty WH, Sims HP. 1978. Some determinants of unethical decision behavior: An experiment. Journal of Applied Psychology 64 451-457 doi.org/10.2466/pr0.1985.57.2.355

Holley D. 2017. General Biology 2: Organisms and Ecology. Indianapolis: Dog Ear Publishing

Hortensius R, Gelder B. 2018. From Empathy to Apathy: The Bystander Effect Revisited. Current Directions in Psychological Science 27:(4) 249-256 doi.org/10.1177/0963721417749653

Kish-Gephart JJ, Harrison DA, Trevino LK. 2010. Bad apples, bad cases, and bad barrels: Metaanalytic evidence about sources of unethical decisions at work. Journal of Applied Psychology 95 1-31 doi.org/10.1037/a0017103

Knechtle B, Nikolaidis PT. 2018. Physiology and Pathophysiology in Ultra-Marathon Running. Frontiers in physiology 9: 634 doi.org/10.3389/fphys.2018.00634

Krakovsky M. 2015. The Middleman Economy: How Brokers, Agents, Dealers, and Everyday Matchmakers Create Value and Profit. New York: Palgrave Macmillan

Latané B, Darley J. 1969. Bystander "Apathy". American Scientist 57:(2) 244-268 jstor.org/stable/27828530

Lin P-I, Fei L, Barzman D, Hossain M. 2018. What have we learned from the time trend of mass shootings in the U.S.? PLoS ONE 13(10): e0204722 doi.org/10.1371/journal.pone.0204722

Lizzeri A. 1999. Information revelation and certification intermediaries, The RAND Journal of Economics 214-231 jstor.org/stable/2556078

Macdonald C. 2019. Money, a disconnecting agent: Reminders of money trigger a feeling of disconnection which increases the likelihood of unethical decisions. Open Science Journal, 4:(1) 110 doi.org/10.23954/osj.v4i1.2200

Mead NL, Baumeister RF, Gino F, Schweitzer ME, Ariely D. 2009. Too tired to tell the truth: Selfcontrol resource depletion and dishonesty. Journal of Experimental Social Psychology 45 594-597 doi.org/10.1016/j.jesp.2009.02.004

Millet GP, Millet GY. 2012. Ultramarathon is an outstanding model for the study of adaptive responses to extreme load and stress. BMC Medicine 10:(77) doi.org/10.1186/1741-7015-10-77

Plötner M, Over H, Carpenter M, Tomasello M. 2015. Young children show the bystander effect in helping situations. Psychological Science 499-506 doi.org/10.1177/0956797615569579

Powell DJ, Attia P, Ghetie V, Schindler J, Vitetta ES, Rosenberg SA. 2008. Partial Reduction of Human FOXP3 + CD4 $\mathrm{T}$ Cells In Vivo After CD25-directed Recombinant Immunotoxin Administration. Journal of immunotherapy 31(2): 189-198 doi.org/10.1097/CJI.0b013e31815dc0e8

Roh BR, Jung EH, Hong HJ. 2018. A Comparative Study of Suicide Rates among 10-19-Year-Olds in 29 OECD Countries. Psychiatry investigation 15:(4) 376-383 doi.org/10.30773/pi.2017.08.02

Rosenthal R. 1966. Experimenter effects in behavioral research. New York: Appleton-Century-Crofts

Rubinstein A, Wolinsky A. 1987. Middlemen, The Quarterly Journal of Economics 102(3): 581593doi.org/10.2307/1884218

Rust J, Hall G. 2003. Middlemen versus Market Makers: A Theory of Competitive Exchange, Journal of Political Economy, University of Chicago Press 111(2): 353-403 ideas.repec.org/a/ucp/jpolec/v111y2003i2p353-403.html

Scientific American. 2012. The Other Oil Problem. Scientific American 307:(6) 10 doi.org/10.1038/scientificamerican1212-10

Stewart WK, Fleming LW. 1973. Features of a successful therapeutic fast of 382 days' duration. Postgraduate medical journal 49:569 203-209 ncbi.nlm.nih.gov/pmc/articles/PMC2495396/

Stone L. 2019. Quantifying the Holocaust: Hyperintense kill rates during the Nazi genocide

Science Advances 5:(1)doi.org/10.1126/sciadv.aau7292

Tangney JP, Stuewig J, Mashek DJ. 2007. Moral emotions and moral behavior. Annual Review of Psychology 58 345-372 doi.org/10.1146/annurev.psych.56.091103.070145

Tenbrunsel AE, Smith-Crowe K. 2008. Ethical decision making: Where we've been and where we're going. The Academy of Management Annals 2 545-607doi.org/10.1080/19416520802211677

Tenbrunsel AE, Smith-Crowe K, Umphress EE. 2003. Building houses on rocks: The role of the ethical infrastructure in organizations. Social Justice Research $16 \quad 285-307$ doi.org/10.1023/A:1025992813613

Trevino LK, Weaver GR, Reynolds S. 2006. Behavioral ethics in organizations: A review. Journal of Management 32 951-990 doi.org/10.1177/0149206306294258 
Valentine ME. 1980. The attenuating influence of gaze upon the bystander intervention effect. Journal of Social Psychology 111:(2) 197 psycnet.apa.org/record/1981-25777-001

Visser TAW, Roberts A. 2018. Automaticity of social cues: The influence of limiting cognitive resources on head orientation cueing, Scientific Reports 8:(10288) nature.com/articles/s41598-01828548-x

Warneken F, Tomasello M. 2006. Altruistic Helping in Human Infants and Young Chimpanzees. Science 311:(5765) 1301-1303 doi.org/10.1126/science.1121448

Webber K. 2017. How Fast Fashion Is Killing Rivers Worldwide. EcoWatch Mar 22 ecowatch.com/fast-fashion-riverblue-2318389169.html

Wright R, Wong YY. 2014. Buyers, Sellers, And Middlemen: Variations On Search-Theoretic Themes, International Economic Review 55:(2) 375-397 